\title{
ANALISIS KESALAHAN BERBAHASA INDONESIA PADA KARANGAN EKSPOSISI SISWA KELAS X MIPA (STUDI KASUS DI SMA NEGERI 4 SURAKARTA)
}

\author{
Feny Oktaviani, Muhammad Rohmadi, Purwadi \\ Universitas Sebelas Maret \\ Surel: feny.oktaviani01@student.uns.ac.id
}

\begin{abstract}
This study aims to describe and explain the form of language errors in the field of phonology, morphology, and syntax in the exposition essay of the student of X MIPA SMA $N 4$ Surakarta and describe the causes of language errors and efforts that can be done by teachers and students so that the Indonesian language error in the exposition essay by the students of X MIPA SMA N 4 Surakarta can be minimized. The research uses qualitative method with case study type. Research data in the form of Indonesian language error obtained through the exposition essay by the student of X MIPA and the data source used are documents and informants. Data collection technique conducted through observation, interviews, dan test. Data validity test used is triangulation method, informant review, dan intrarater. The result of this research are description of: (1) forms of language errors in the phonological field include capitalization misuse, misuse of punctuation, particle error, rewrite error, typographic error, and typing error; (2) the form of language error in the morphological field include mistakes of preposition, mistake of word formation, and error of pleonasm; (3) the form of language error in the syntax field include the phrase structure dan sentence structure; and (4) the factors causing the Indonesian language error not only comes from the students but also because of teacher and efforts that can be done to minimize language errors.
\end{abstract}

Keywords: language error, exposition essay

\begin{abstract}
Abstrak: Penelitian ini bertujuan untuk menjelaskan bentuk kesalahan berbahasa dalam karangan eksposisi siswa kelas X MIPA SMA N 4 Surakarta serta menjelaskan dan mendeskripsikan penyebab adanya kesalahan berbahasa dan upaya yang dapat dilakukan oleh guru dan siswa agar kesalahan berbahasa Indonesia dalam karangan eksposisi siswa kelas X SMA N 4 Surakarta dapat diminimalisasi. Penelitian ini merupakan studi kasus dengan data penelitian berupa kesalahan berbahasa Indonesia dalam karangan eksposisi siswa kelas X MIPA. Teknik pengumpulan data dilakukan melalui observasi, wawancara, dan tes. Uji validitas data yang digunakan adalah triangulasi metode, review informan, dan intrarater. Hasil penelitian ini adalah deskripsi tentang: (1) bentuk kesalahan berbahasa meliputi kesalahan penggunaan huruf kapital, kesalahan penggunaan tanda baca, kesalahan penggunaan partikel, kesalahan penulisan kata ulang, kesalahan akibat tipografi, dan kesalahan penulisan kata baku; (2) bentuk kesalahan berbahasa pada bidang morfologi meliputi kesalahan penulisan kata depan, kesalahan penulisan kata bentukan, dan kesalahan akibat pleonasme; (3) bentuk kesalahan berbahasa pada bidang sintaksis meliputi kesalahan struktur frasa-struktur kalimat; dan (4) faktor penyebab terjadinya kesalahan berbahasa bukan hanya berasal dari siswa melainkan juga karena faktor guru.
\end{abstract}

Kata kunci: kesalahan berbahasa, teks eksposisi

BASASTRA Jurnal Bahasa, Sastra, dan Pengajarannya 


\section{PENDAHULUAN}

Bahasa merupakan salah satu aspek penting untuk menunjang keberhasilan dalam mempelajari semua bidang studi. Bahasa juga menjadi instrumen penting dalam komunikasi sehingga tanpa bahasa manusia akan kesulitan untuk menyampaikan pendapat, gagasan, maupun ide yang mereka pikirkan. Dalam kehidupan, kita menggunakan bahasa untuk berpikir, menyimak, berbicara, membaca, dan menulis. Bahasa adalah sistem simbol bunyi yang bermakna dan berartikulasi (dihasilkan oleh alat ucap) yang bersifat arbitrer dan konvensional, yang dipakai sebagai alat komunikasi oleh sekelompok manusia untuk melahirkan perasaan dan pikiran (Wibowo, 2001: 3). Melalui bahasa, manusia dapat menyampaikan gagasan ataupun ide melalui dua cara yakni secara verbal maupun nonverbal. Secara verbal, gagasan dari seseorang secara langsung dapat ia sampaikan. Sebaliknya, gagasan yang disampaikan secara nonverbal dapat dikemas melalui bahasa tulis.

Pemakaian bahasa tulis akan selalu menjadi bagian penting dalam proses pembelajaran di sekolah. Siswa di sekolah tidak hanya dituntut untuk memiliki keterampilan berbahasa secara verbal, melainkan juga harus memiliki keterampilan dalam bahasa tulis. Pengembangan kemampuan berbahasa siswa dapat dilakukan dengan adanya pembelajaran keterampilan berbahasa dalam mata pelajaran Bahasa Indonesia. Pembelajaran keterampilan berbahasa bertujuan untuk meningkatkan kemampuan intelektual, kematangan emosional, dan kematangan sosial. Di samping itu, dari pembelajaran keterampilan berbahasa siswa diharapkan dapat menyaring hal-hal yang berguna, belajar menjadi diri sendiri dan menyadari eksistensi budayanya sehingga tidak tercabut dari lingkungannya (Depdiknas, 2003: 5).

Terdapat empat aspek keterampilan berbahasa yang mencakup dalam pembelajaran bahasa, yaitu keterampilan menyimak dan keterampilan membaca yang termasuk ke dalam kemampuan reseptif serta keterampilan berbicara dan keterampilan menulis yang termasuk ke dalam kemampuan produktif (Tarigan, 2008: 257). Dari keempat keterampilan tersebut, keterampilan menulis adalah keterampilan yang paling kompleks dimana menulis merupakan salah satu 
kompetensi bahasa dalam setiap jenjang pendidikan mulai dari sekolah dasar hingga perguruan tinggi. Menulis digunakan oleh orang terpelajar untuk mencatat, merekam, menyakinkan, melaporkan atau memberitahukan dan mempengaruhi, dan maksud serta tujuan seperti itu hanya dapat dicapai oleh orang-orang yang dapat menyusun pikirannya dan mengutarakan dengan jelas (Morsey, dalam Tarigan, 2008: 4). Melalui kegiatan menulis, siswa akan melatih diri untuk mengembangkan gagasan yang dikemas melalui bahasa yang sesuai lewat sebuah tulisan. Aktivitas menulis merupakan salah satu bentuk manifestasi keterampilan berbahasa paling akhir yang dikuasai oleh pembelajar bahasa setelah mereka menguasai keterampilan menyimak, berbicara, dan membaca (Nurgiyantoro, 2001: 296).

Keterampilan menulis lebih sulit dikuasai daripada ketiga keterampilan berbahasa yang lain karena keterampilan menulis membutuhkan penguasaan berbagai unsur kebahasaan dan unsur di luar bahasa untuk dapat menghasilkan sebuah karangan yang runtut dan padu. Menulis menjadi salah satu pembelajaran yang penting karena seseorang yang dapat membuat suatu tulisan dengan baik berarti ia telah menguasai tata bahasa, mempunyai kebendaharaan kata, dan mempunyai kemampuan menuangkan ide atau gagasan dalam bentuk tulisan. Dengan demikian, tulisan siswa dapat dijadikan sebagai salah satu tolak ukur keberhasilan siswa dalam pembelajaran bahasa Indonesia (Sukman, 2005: 30).

Salah satu wujud pembelajaran menulis dalam mata pelajaran bahasa Indonesia adalah kegiatan mengarang. Karangan adalah hasil penjabaran suatu gagasan secara resmi dan teratur tentang suatu topik atau pokok bahasan (Finoza, 2002: 184). Karangan merupakan sebuah tulisan yang teratur menurut urutanurutan yang logis dan setiap unsurnya harus memiliki kesatuan dan kepaduan. Karangan memiliki beberapa jenis, salah satunya adalah karangan eksposisi. Karangan eksposisi merupakan bentuk pengembangan karangan yang bertujuan untuk memberi tahu,mengupas, menguraikan, atau menerangkan sesuatu yang strukturnya terdiri atas pembukaan, tesis (pendapat), argumen yang berupa ulasan, dan penutup (Finoza, 2002: 192). Tujuan karangan eksposisi adalah memberi informasi dan tambahan pengetahuan bagi pembaca. Oleh karena itu, hendaknya 
penulis (siswa) mampu menuangkan gagasannya secara sistematis, runtut, dan lengkap. Namun kenyataannya, masih banyak persoalan yang dihadapi siswa dalam membuat karangan eksposisi. Beberapa persoalan yang sering dihadapi siswa dalam membuat karangan eksposisi antaralain kurangnya motivasi untuk mengarang, siswa kesulitan dalam menentukan tema, siswa kurang memiliki penguasaan kaidah berbahasa, minimnya referensi dan informasi, dan sulitnya merangkai argumen dalam bentuk tulis. Beberapa kendala tersebut jelas menyebabkan rangkaian kalimat yang ditulis oleh siswa mengandung kesalahan berbahasa sehingga karangan yang dihasilkan kurang berkualitas.

Menulis tidak bisa dikatakan sebagai kegiatan yang mudah karena untuk menghasilkan tulisan yang baik maka diperlukan pula keterampilan berbahasa yang mencukupi. Sekurang-kuranganya ada tiga komponen yang tergabung dalam kegiatan menulis yaitu: (1) penguasaan bahasa tulis, meliputi kosakata, struktur, kalimat, paragraf, ejaan, pramagtik, dan sebagainya; (2) penguasaan isi karangan sesuai dengan topik yang akan ditulis; dan (3) pengusaan tentang jenis-jenis tulisan, yaitu bagaimana merangkai isi tulisan dengan menggunakan bahasa tulis sehingga membentuk sebuah komposisi yang diinginkan (Tarigan, 2008: 26). Sesuai hasil observasi peneliti yang dilaksanakan di kelas X MIPA SMA N 4 Surakarta, menulis eksposisi seringkali masih menjadi hal yang sulit bagi siswa. Secara garis besar, kesalahan berbahasa masih sering ditemukan dalam teks eksposisi karya siswa. Akan tetapi kesalahan berbahasa timbul bukan hanya karena faktor siswa, melainkan juga berasal dari faktor guru. Metode pembelajaran yang kurang tepat mengakibatkan pemahaman siswa menjadi kurang sehingga tulisan yang dihasilkan juga kurang maksimal. Menurut hasil observasi peneliti, pada saat pembelajaran teks eksposisi guru hanya menggunakan metode ceramah, teori disampaikan cukup singkat dan siswa hanya diberikan contoh teks eksposisi dari buku teks yang digunakan. Hal ini tentu berpengaruh pada rendahnya tingkat pemahaman siswa.

Kesalahan berbahasa merupakan suatu bagian belajar yang tidak terhindarkan oleh siswa. James (dalam Na Phuket, 2015: 100) berpendapat, "Committing errors is an inevitable circumstance that occurs in human learning, 
including language" (Terjadinya kesalahan adalah kondisi yang tidak dapat terelakkan yang terjadi dalam proses belajar manusia, termasuk bahasa). Kesalahan berbahasa umum terjadi, tetapi tidak boleh dibiarkan begitu saja karena semakin tinggi tingkat kesalahan berbahasa siswa, maka pencapaian tujuan pengajaran berbahasa akan semakin rendah. Hal tersebut sejalan dengan Sattayathan (2008: 22) yang berpendapat, "Errors are the result of some failure of performance" (Kesalahan adalah hasil dari beberapa kegagalan kinerja).

Kesalahan berbahasa umumnya disebabkan oleh faktor kompetensi, artinya siswa memang belum memahami sistem linguistik bahasa yang digunakan. Maka dari itu dalam menghadapi persoalan ini sangat diperlukan upaya untuk meminimalkan kesalahan berbahasa dalam teks karangan siswa. Hal ini dapat tercapai dengan cara mengkaji secara mendalam seluk beluk kesalahan tersebut. Pengkajian segala aspek kesalahan berbahasa itulah yang disebut analisis kesalahan berbahasa. Analisis kesalahan berbahasa adalah suatu proses kerja yang digunakan oleh para guru dan peneliti bahasa dengan langkah-langkah pengumpulan data, pengidentifikasian kesalahan yang terdapat di dalam data, penjelasan kesalahan, pengklasifikasian kesalahan berdasarkan penyebab, serta pengevaluasian taraf keseriusan kesalahan itu (Tarigan, 1996: 68). Melalui kegiatan analisis kesalahan berbahasa dalam karangan siswa, diharapkan hasil dari analisis tersebut nantinya mampu dijadikan langkah untuk meningkatkan kualitas siswa dalam menerapkakan kaidah berbahasa Indonesia dalam setiap tulisannya. Crystal sebagaimana dikutip oleh Pateda (1989: 32) menyatakan:

"Analisis kesalahan berbahasa adalah suatu teknik untuk mengidentifikasi, mengklasifikasikan, dan menginterpretasikan secara sistematis kesalahankesalahan yang dibuat siswa yang sedang belajar bahasa asing atau bahasa kedua dengan menggunakan teori-teori dan prosedur-prosedur berdasarkan linguistik. Dari analisis tersebut akan diperoleh: (1) deskpripsi kesalahan; (2) peringkat kesalahan: dan (3) perbaikan kesalahan tersebut."

Analisis kesalahan berbahasa juga dapat digunakan sebagai umpan balik dalam upaya memperbaiki dan menyempurnakan pengajaran bahasa (Ariningsih, Sumarwati \& Sadhonno, 2012). Mengetahui kesalahan berbahasa siswa dapat 
memberikan beberapa keuntungan, diantaranya untuk mengetahui penyebab kesalahan itu, untuk memperbaiki kesalahan yang dilakukan, dan untuk mencegah atau menghindari terjadinya kesalahan sejenis di waktu yang akan datang (Tarigan, 1996: 127). Analisis kesalahan berbahasa dapat dilakukan dengan menganalisis pada bidang linguistik, seperti fonologi, morfologi, sintaksis, semantik, dan wacana. Akan tetapi dalam penelitian ini peneliti lebih fokus menganalisis karangan pada tataran fonologi, morfologi, dan sintaksis. Dalam suatu karangan, wujud kesalahan bidang fonologi adalah kesalahan dalam penggunaan ejaan, seperti penggunaan huruf kapital, huruf miring, tanda baca, lambing bilangan, dan lain-lain (Markhamah dan Atiqa, 2011: 77). Selanjutnya, kesalahan bidang morfologi dalam bahasa Indonesia berhubungan dengan derivasi, diksi, dan pleonasme (Pateda, 1989: 53). Sedangkan kesalahan sintaksis adalah kesalahan karena penyimpangan struktur frasa, klausa, atau kalimat, serta ketidaktepatan pemakaian partikel. Analisis dalam bidang tata kalimat menyangkut urutan kata, kepaduan, sususan frasa, kepaduan kalimat, dan logika kalimat (Markhamah, 2011: 143). Berdasarkan uraian tersebut, peneliti tertarik untuk menganalisis kesalahan berbahasa Indonesia dalam karangan eksposisi siswa kelas X MIPA SMA N 4 Surakarta.

\section{METODEPENELITIAN}

Metode penelitian yang digunakan dalam penelitian ini adalah metode kualitatif dengan tipe studi kasus. Syamsudin (2009: 175) membatasi pendekatan studi kasus sebagai suatu pendekatan dengan memusatkan perhatian pada satu kasus secara intensif dan rinci. Dalam penelitian ini masalah telah difokuskan pada satu kasus, yaitu mengenai kesalahan berbahasa Indonesia. Penelitian ini berusaha untuk mendeskripsikan berbagai kesalahan berbahasa Indonesia dalam karangan eksposisi siswa kelas X MIPA SMA N 4 Surakarta dengan menekankan analisis pada bidang fonologi, morfologi, dan sintaksis. Data penelitian berupa kesalahan berbahasa Indonesia dalam karangan eksposisi siswa dan sumber data yang digunakan adalah dokumen dan informan. Teknik pengambilan subjek penelitian dengan purposive sampling dan teknik pengumpulan data dilakukan 
melalui observasi, wawancara, dan tes. Observasi dilaksanakan pada proses pembelajaran menulis teks eksposisi di kelas X MIPA 1, 2, dan 3 SMA N 4 Surakarta. Peneliti melalukan wawancara dengan guru bahasa Indonesia dan beberapa siswa dari kelas X MIPA 1, 2, dan 3 SMA N 4 Surakarta. Uji validitas data yang digunakan adalah triangulasi metode, review informan, dan intrarater. Teknik analisis data yang digunakan adalah model analisis interaktif.

\section{HASIL PENELITIAN DAN PEMBAHASAN}

\section{Bentuk Kesalahan Berbahasa pada Bidang Fonologi}

Kesalahan bidang fonologi adalah kesalahan yang berhubungan dengan pelafalan dan penulisan bunyi bahasa (Markhamah, 2011: 76-77). Dalam penelitian ini, bentuk kesalahan berbahasa pada bidang fonologi meliputi kesalahan penggunaan huruf kapital, penggunaan tanda baca (titik dan koma), penggunaan partikel, kesalahan penulisan kata ulang, kesalahan akibat tipologi, dan kesalahan penulisan kata baku.

Beberapa contoh bentuk kesalahan berbahasa pada bidang fonologi yang ditemukan dalam penelitian ini adalah sebagai berikut:

Perlukah ketegasan Hukum Bagi pengguna Narkoba di Indonesia?

$(\mathrm{AKB} / 02)$

Kalimat di atas adalah kalimat yang digunakan untuk penulisan judul. Kata "ketegasan" di dalam judul seharusnya diawali dengan huruf kapital. Kata "bagi" dalam judul tidak diawali dengan huruf kapital karena merupakan preposisi yang bermakna "untuk". Dan kata "pengguna" dalam judul seharusnya diawali dengan huruf kapital.

Apalagi, sekarang, Indonesia sudah mempunyai lembaga khusus yang menangani kasus narkoba, yaitu BNN (Badan Narkotika Nasional). $(\mathrm{AKB} / 05)$

Pada kalimat di atas, penggunaan tanda koma dalam kalimat di atas terlalu banyak dan seharusnya tanda koma cukup digunakan sesudah frasa "apalagi sekarang”. 
Penyelundupan barang haram tersebut juga banyak terjadi di Indonesia, mulai dari jalur darat, udara, maupun jalur" yang lain. (AKB/01)

Pada kalimat di atas, penggunaan tanda petik sebagai singkatan untuk menulis kata ulang tidak diperbolehkan, karena kata ulang harus disambung menggunakan tanda hubung (-).

Sudah shrusnya seluruh masyarakat Indonesia sadar akan bahaya narkoba sehingga tidak menggunakannya. (AKB/03)

Pada kalimat di atas, kata shrusnya dalam kalimat di atas termasuk dalam kesalahan ortografis karena penulisannya yang keliru sehingga maknanya tidak jelas. Kata yang benar adalah seharusnya.

Semakin modern tehnologi kita saat ini maka semakin rawan terjadi kasuskasus yang menyangkut tentang narkotika. (AKB/01)

Efektif tidaknya suatu kalimat dipengaruhi oleh unsur kecermatan, salah satunya kecermatan dalam hal penulisan kata baku. Tehnologi merupakan kata yang tidak baku karena yang baku adalah teknologi.

Temuan dalam penelitian ini sejalan dengan hasil temuan Rahmawati (2014) yang menyimpulkan bahwa kesalahan pada bidang fonologi dalam soal ujian nasional tahun 2013 cukup bervariasi, diantaranya adalah kesalahan penulisan huruf kapital, tanda baca, kesalahan penulisan partikel, kesalahan ortografis, dan kesalahan dalam hal diksi yang tidak baku. Sementara itu, penelitian Susanti (2016) juga menyimpulkan bahwa dalam analisis kesalahan berbahasa, bidang fonologi akan selalu mendominasi kesalahan yang meliputi kesalahan penulisan tanda baca, kesalahan penulisan singkatan, kesalahan penggunaan huruf kapital, kesalahan pemilihan diksi, dan kesalahan penggunaan ejaan. Penelitian lainnya adalah penelitian Syahriandi (2014) yang menyimpulkan bahwa analisis kesalahan berbahasa pada media cetak juga didominasi oleh kesalahan ejaan dan diksi. Kesalahan ejaan meliputi kesalahan penggunaan huruf, tanda baca, penggunaan partikel, penggunaan tanda hubung, dan penggunaan diksi sesuai kaidah baku yang semuanya termasuk dalam kesalahan pada bidang fonologi. 


\section{Bentuk Kesalahan Berbahasa pada Bidang Morfologi}

Dalam penelitian ini, bentuk kesalahan berbahasa pada bidang morfologi difokuskan pada kesalahan penulisan kata depan, kesalahan penulisan kata bentukan, dan kesalahan akibat pleonasme. Beberapa contoh bentuk kesalahan berbahasa pada bidang morfologi yang ditemukan dalam penelitian ini adalah sebagai berikut:

Masyarakat banyak yang tidak setuju jika pengguna narkoba hanya di rehabilitasi karena setelah rehabilitasi tidak ada jaminan bahwa mereka telah merasa jera. (AKB/06)

Dalam kalimat di atas, kata rehabilitasi merupakan kata benda (noun) sehingga preposisi di tidak perlu dipisah dengan kata tersebut.

Hukum yang cukup ketat seharusnya mampu mensadarkan masyarakat akan pentingnya menjauhi narkoba. (AKB/07)

Dalam kalimat di atas, kata mensadarkan adalah salah karena penulisannya tidak sesuai dengan kaidah ejaan yang benar. Kata yang benar adalah menyadarkan karena kata bentukan tersebut berasal dari kata sadar yang mendapat awalan me- dan akhiran -kan. Sesuai dengan kaidah bahasa Indonesia, afiks meyang bertemu dengan kata dasar berawalan huruf $\mathrm{K}, \mathrm{T}, \mathrm{S}$, dan $\mathrm{P}$ maka huruf tersebut akan hilang atau melebur.

Pemerintah perlu melakukan usaha dan upaya lebih untuk benar-benar mampu memberantas narkoba. (AKB/09)

Dalam kalimat di atas, kata usaha dan upaya memiliki makna yang sama yaitu mengerahkan tenaga sebagai bentuk ikhtiar untuk mencapai sesuatu sehingga dalam kalimat di atas cukup ditulis salah satu saja agar lebih efektif.

Hasil penelitian ini sejalan dengan hasil penelitian Wijayanti (2014) yang menyimpulkan bahwa dalam bidang morfologi, kesalahan berbahasa yang paling dominan ditemukan adalah kesalahan akibat pleonasme yang kemudian disusul oleh kesalahan penulisan kata depan. Hanya saja dalam penelitian Wijayanti terdapat lebih banyak aspek kesalahan lain yang ditemukan seperti kesalahan mengganti prefiks ter- dengan prefiks ke-, kesalahan mengjilangkan prefiks terdan ber-, serta kesalahan penulisan sufiks -nya. Hal tersebut tidak ditemukan 
dalam penelitian ini karena data yang digunakan adalah hasil karangan siswa SMA, sehingga kesalahan pada aspek imbuhan yang ditemukan hanyalah kesalahan pada penulisan kata bentukan yang hanya berjumlah tiga buah. Sedangkan penelitian Wijayanti tersebut mengkaji hasil karangan siswa SMP kelas VII semester 1 yang notabene adalah siswa yang baru saja lulus dari sekolah dasar sehingga kesalahan dalam bidang morfologi pada aspek imbuhan jauh lebih banyak ditemukan.

Sementara itu hasil temuan Fortuna (2014) juga tidak jauh berbeda dengan hasil penelitian ini, yakni kesalahan berbahasa dalam bidang morfologi yang ditemukan dalam karangan siswa kelas VII SMP N 1 Godong terdiri dari kesalahan akibat pleonasme yang menjadi paling dominan, kesalahan penulisan kata depan, dan beberapa kesalahan penggunaan imbuhan karena karangan yang diteliti adalah karangan siswa kelas VII yang lebih memungkinkan untuk melakukan kesalahan penulisan imbuhan jauh lebih banyak dibandingkan siswa SMA. Sementara itu, penelitian oleh Purwaningsih (2016) menyimpulkan bahwa kesalahan pada bidang morfologi dalam penulisan surat dinas didominasi oleh kesalahan penulisan kata depan, yang kemudian disusul oleh kesalahan penulisan kata bentukan, dan kesalahan akibat pleonasme. Penelitian tersebut sejalan dengan hasil penelitian ini yang juga menemukan kesalahan pada tiga aspek, yakni kesalahan penulisan kata depan, yang kemudian disusul oleh kesalahan penulisan kata bentukan, dan kesalahan akibat pleonasme.

\section{Bentuk Kesalahan Berbahasa pada Bidang Sintaksis}

Dalam penelitian ini, kesalahan pada bidang sintaksis terdiri dari kesalahan penggunaan struktur frasa dan kesalahan penggunaan struktur kalimat. Kesalahan penggunaan struktur frasa terdiri atas susunan kata yang tidak tepat, penggunaan unsur berlebihan, penggunaan bentuk superlatif yang berlebihan, dan penjamakan bentuk jamak. Sedangkan kesalahan penggunaan struktur kalimat terdiri atas kalimat yang tidak lengkap, penggunaan konjungsi yang berlebihan, struktur kalimat tidak sejajar, dan kalimat tidak logis. 
Beberapa contoh bentuk kesalahan berbahasa pada bidang sintaksis yang ditemukan dalam penelitian ini adalah sebagai berikut:

Kesalahan penggunaan struktur frasa

Apabila pemerintah semakin memperkuat aparat dan mempertegas sanksi hukum maka tidak dibutuhkan terlalu banyak waktu untuk berhasil menangkap seluruh jaringan narkoba yang berhasil masuk ke Indonesia. $(\mathrm{AKB} / 27)$

Pada kalimat di atas, frasa terlalu banyak waktu berasal dari terjemahan bahasa Inggris yaitu too many time. Frasa yang lebih tepat digunakan agar sesuai dengan kaidah bahasa Indonesia adalah waktu terlalu banyak.

Di era globalisasi seperti sekarang, sangat banyak sekali ditemukan kasus penyalahgunaan obat-obatan terlarang terutama di kalangan remaja. $(\mathrm{AKB} / 03)$

Kata-kata yang dicetak tebal dalam kalimat di atas menunjukkan bahwa kalimat di atas belum efektif karena tidak memenuhi unsur kehematan. Sangat banyak sekali menjadi tidak efektif karena cukup dengan ditulis sangat banyak atau banyak sekali maknanya tetap sama sehingga tidak perlu berlebihan.

Para penegak hukum seharusnya melakukan upaya untuk mencari seluruh jaringan pengedar dan bandar narkoba di Indonesia agar tidak ada lagi para korban-korban yang menjadi pengguna narkoba. (AKB/09)

Dalam kalimat di atas, para korban-korban merupakan bentuk penjamakan dari sebuah bentuk jamak. Kata para mengacu pada sebuah kelompok sehingga penulisan korban-korban dibelakang kata para adalah salah karena menjadikan kalimat justru tidak efektif.

Kesalahan Penggunaan Struktur Kalimat

Jika kasus tersebut tidak segera ditangani oleh pihak yang berwajib.

$(\mathrm{AKB} / 14)$

Dalam kalimat di atas, kata ,jika merupakan konjungsi subordinatif yang berfungsi untuk menghubungkan dua klausa atau lebih dengan status yang tidak sama derajatnya guna menjelaskan suatu hubungan syarat. Maka dari itu sebuah klausa saja tidak boleh diawali kata ,jika ${ }^{e e}$ karena maknanya akan menjadi tidak jelas. 
Tetapi karena semakin banyaknya kasus narkoba di kalangan pelajar, orang tua perlu memperketat pengawasan terhadap anak-anaknya. $(\mathrm{AKB} / 14)$

Pada kalimat di atas ditemukan penggunaan konjungsi berlebihan yaitu terdapat konjungsi „tetapie dan „karena ${ }^{\text {ee }}$ sekaligus dalam satu kalimat. Penggunaan konjungsi berlebihan justru menjadikan kalimat tidak efektif.

Lebih baik pemerintah melakukan sosialisasi tentang bahaya narkoba agar narkoba tidak disalahgunakan masyarakat. (AKB/03)

Dalam kalimat di atas, kata melakukan dan disalahgunakan tidak sejajar sehingga kalimat di atas belum efektif. Kata melakukan merujuk pada bentuk aktif sedangkan kata disalahgunakan merujuk pada bentuk pasif.

Temuan dalam penelitian ini sejalan dengan hasil temuan Istinganah (2012) yang juga menemukan kesalahan pada bidang sintaksis berupa kesalahan penggunaan struktur frasa dan kesalahan struktur kalimat. Hanya saja dalam penelitian Istinganah tersebut mengkaji tentang karangan narasi, sedangkan dalam penelitian ini yang dikaji adalah karangan eksposisi. Sementara itu hasil temuan dalam penelitian ini jauh lebih lengkap daripada hasil penelitian Ayuningsih (2012) yang hanya menganalisis kesalahan berbahasa pada bidang sintaksis pada aspek kesalahan struktur kalimat saja. Hasil penelitian ini juga lebih lengkap dibandingkan hasil penelitian Rahmawati (2014) yang juga hanya mengkaji kesalahan struktur kalimat dalam soal ujian nasional tahun 2013.

Penyebab Terjadinya Kesalahan Berbahasa dan Upaya Meminimalisasi Kesalahan Berbahasa

Kesalahan berbahasa bukan hanya disebabkan karena faktor siswa melainkan juga dipengaruhi oleh faktor guru yang berperan dalam proses pengajaran bahasa. Secara spesifik berdasarkan observasi, wawancara, dan perolehan data penelitian di SMA N 4 Surakarta, beberapa penyebab kesalahan berbahasa yang disebabkan oleh faktor guru antaralain adalah kurangnya variasi guru dalam menggunakan metode pembelajaran sehingga berpengaruh pada 
tingkat motivasi siswa untuk belajar bahasa Indonesia dan tingkat pemahaman mereka terhadap materi.

Beberapa penyebab terjadinya kesalahan berbahasa adalah adanya interferensi bahasa ibu, minimnya informasi dan referensi tentang kaidah berbahasa, kurangnya penguasaan kosakata dan pemahaman tentang kalimat efektif, dan yang paling terlihat adalah kurangnya motivasi siswa untuk belajar bahasa Indonesia. Hal ini sejalan dengan hasil penelitian Nurhayatin (2017) yang menyimpulkan bahwa faktor terjadinya kesalahan berbahasa adalah karena motivasi belajar siswa yang rendah sehingga siswa tidak teliti saat menulis dan ingin tulisannya cepat diselesaikan tanpa memperhatikan isi dan membacanya kembali untuk merevisi kesalahan yang mungkin terjadi.

Beberapa langkah yang dapat dilakukan oleh guru untuk meminimalisasi kesalahan berbahasa yang dilakukan oleh siswa diantaranya adalah dengan melakukan kegiatan analisis kesalahan berbahasa, menggunakan model dan metode pembelajaran yang lebih bervariasi agar siswa benar-benar paham dengan materi dan seluk beluk menulis yang membutuhkan pemahaman tentang kalimat efektif, ejaan, diksi, dan lain-lain. Selain itu, dari pihak siswa juga harus ada upaya untuk melakukan perbaikan diantaranya adalah dengan memunculkan kesadaran akan budaya literasi sehingga mereka akan terbiasa membaca dan menulis yang secara otomatis akan mengembangkan pemahaman mereka tentang kaidah berbahasa dan memperkaya kosakata.

\section{Persebaran Kesalahan Berbahasa}

Setelah analisis kesalahan berbahasa dilakukan pada 45 teks eksposisi karya siswa kelas X MIPA SMA N 4 Surakarta, perlu adanya rekapitulasi atau perhitungan kesalahan yang telah tercatat untuk memperjelas bentuk dan besaran kesalahan yang terjadi. Untuk mempermudah perhitungan atau rekapitulasi maka perlu dibuat gambaran kesalahan yang terjadi dalam bentuk tabel 1 sebagai berikut:

\begin{tabular}{cll}
\hline Jenis Kesalahan Berbahasa & Jumlah & $\begin{array}{l}\text { Persen- } \\
\text { tase }\end{array}$ \\
\hline Penggunaan huruf kapital & 11 & $8,4 \%$ \\
\hline
\end{tabular}




\begin{tabular}{|c|c|c|c|}
\hline \multirow{6}{*}{$\begin{array}{l}\text { Bidang } \\
\text { Fonologi }\end{array}$} & Penggunaan tanda titik & 16 & $12,4 \%$ \\
\hline & Penggunaan tanda koma & 7 & $5,3 \%$ \\
\hline & Penggunaan partikel & 2 & $1,5 \%$ \\
\hline & Penulisan kata ulang & 11 & $8,4 \%$ \\
\hline & Kesalahan akibat tipografi & 9 & $6,8 \%$ \\
\hline & Penulisan kata baku & 8 & $6,1 \%$ \\
\hline \multirow{3}{*}{$\begin{array}{l}\text { Bidang } \\
\text { Morfologi }\end{array}$} & Penulisan kata depan & 10 & $7,6 \%$ \\
\hline & Penulisan kata bentukan & 3 & $2,2 \%$ \\
\hline & Kesalahan akibat pleonasme & 16 & $12,4 \%$ \\
\hline \multirow{8}{*}{$\begin{array}{l}\text { Bidang } \\
\text { Sintaksis }\end{array}$} & Susunan kata tidak tepat & 1 & $0,8 \%$ \\
\hline & Penggunaan unsur berlebihan & 6 & $4,6 \%$ \\
\hline & Penggunaan bentuk superlatif berlebihan & 4 & $3,1 \%$ \\
\hline & Penjamakan bentuk jamak & 5 & $3,8 \%$ \\
\hline & Kalimat tidak lengkap & 7 & $5,3 \%$ \\
\hline & Penggunaan konjungsi berlebihan & 3 & $2,2 \%$ \\
\hline & Struktur kalimat tidak sejajar & 6 & $4,6 \%$ \\
\hline & Kalimat tidak logis & 6 & $4,6 \%$ \\
\hline Total & & 131 & \\
\hline
\end{tabular}

Tabel.1

\section{SIMPULAN}

Berdasarkan rumusan, tujuan, hasil, dan pembahasan terkait dalam penelitian ini dapat ditarik beberapa kesimpulan. Pertama, bentuk kesalahan berbahasa pada bidang fonologi yang ditemukan dalam karangan eksposisi siswa kelas X MIPA SMA N 4 Surakarta meliputi kesalahan penggunaan huruf kapital, kesalahan penggunaan tanda baca, kesalahan penggunaan partikel, kesalahan penulisan kata ulang, kesalahan ortografis, dan kesalahan penulisan kata baku. Kesalahan paling dominan pada bidang fonologi adalah kesalahan penggunaan tanda titik. Kedua, bentuk kesalahan berbahasa pada bidang morfologi yang ditemukan dalam karangan eksposisi siswa kelas X MIPA SMA N 4 Surakarta meliputi kesalahan penulisan kata depan, kesalahan penulisan kata bentukan, dan kesalahan akibat pleonasme. Kesalahan paling dominan pada bidang morfologi dalam penelitian ini adalah kesalahan akibat pleonasme. Ketiga, bentuk kesalahan berbahasa pada bidang sintaksis yang ditemukan dalam karangan eksposisi siswa kelas X MIPA SMA N 4 Surakarta meliputi kesalahan struktur frasa dan struktur kalimat. Kesalahan struktur frasa meliputi susunan kata yang tidak tepat, 
penggunaan unsur berlebihan, penggunaan bentuk superlatif yang berlebihan, dan penjamakan bentuk jamak.

Kesalahan struktur kalimat terdiri dari kalimat tidak lengkap, penggunaan konjungsi berlebihan, struktur kalimat tidak sejajar, dan kalimat tidak logis. Terakhir, Faktor-faktor yang menyebabkan adanya kesalahan berbahasa tidak sepenuhnya berasal dari siswa melainkan juga berasal dari guru. Penggunaan metode pembelajaran yang tidak tepat menyebabkan pemahaman siswa tentang kaidah berbahasa tidak maksimal. Ada banyak cara untuk menanggulangi kesalahan berbahasa yang terjadi, salah satunya adalah melalui analisis kesalahan berbahasa yang dilakukan oleh guru untuk mengetahui jenis kesalahan dan faktor penyebab kesalahan yang dilakukan oleh siswa. Selain itu upaya untuk meningkatkan motivasi belajar bahasa Indonesia bagi siswa dengan mengembangkan budaya literasi juga perlu dilakukan agar siswa secara mandiri dapat meningkatkan pemahaman mereka tentang kaidah berbahasa guna meminimalisasi kesalahan berbahasa yang mungkin terjadi kembali.

\section{DAFTAR PUSTAKA}

Ariningsih, N.E., Sumarwati \& Sadhonno, K. (2012). Analisis Kesalahan Berbahasa Indonesia dalam Karangan Eksposisi Siswa Sekolah Menengah Atas. Jurnal BASATRA, 1 (1) , 40-53.

Ayuningsih, F. (2012). "Analisis Kesalahan Berbahasa pada Penulisan Pengalaman Pribadi Siswa Kelas X A SMK Batik 2 Surakarta". Varia Pendidikan. Vol 2, No. 4, ISSN 231-1436

Fortuna, H. (2014). "Analisis Kesalahan Berbahasa dalam Bidang Morfologi pada Karangan Siswa Kelas VII G SMP N 1 Godong". Varia Pendidikan. Vol 3, No. 2, ISSN 1200-2345.

Istinganah, N... "Analisis Kesalahan Sintaksis pada Karangan Narasi Ekspositoris Siswa Kelas VIII SMP N 1 Banguntapan, Bantul, Yogyakarta". LITERA. Vol. 3, No. 2, ISSN 2134-3456. (http://ejournal.litera.ac.id/index.php/jret). Diakses pada tanggal 16 Maret 2018.

Na Phuket, Pimpisa Rottanadilok. 2015. "Understanding EFL Students Errors in Writing. Journal of Education and Practice". Vol. 6, ISSN 22222888. (http://iiste.org) . Diakses pada tanggal 11 Maret 2018. 
Nurhayatin, Titin. 2017. "Analisis Keefektifan Penggunaan Kalimat dalam Karya Tulis Ilmiah Siswa Kelas X SMA N 4 Bandung”. JPSD. Vol. 4, ISSN 2540-9093.

Pateda, Mansoer. 1989.Analisis Kesalahan Berbahasa. Flores: Nusa Indah.

Purwaningsih, Setyo. 2016. "Kesalahan Berbahasa Bidang Fonologi dan Morfologi dalam Penulisan Surat Dinas di SMK Harapan Kartasura". Varia Pendidikan. Vol. 3, No. 2, ISSN 2341-2003.

Rahmawati, Etika Laili, dkk. 2014. "Analisis Kesalahan Berbahasa pada 20 Paket Soal Ujian Nasional Bahasa Indonesia SMP 2012/2013". Varia Pendidikan. Vol. 6, No. 2, ISSN 1334-1890. (http://ejournal.varia pendidikan.ac.id/index.php/jret). Diakses pada tanggal 16 Maret 2018.

Sattayathan Anchalee \& Ratanapinyowong Pongrat. 2008. "Analysis of Errors in Paragraph Writing in English by First Year Medical Students from the Four Medical Schools at Mahidol University". Silpakorn University International Journal. Vol.8 (17-38). (http://thai science.info/journals/article). Diakses pada Tanggal 12 Januari 2017.

Sumarwati. (2016). Keefektifan Model Pembela-jaran Tata Bahasa dan Keterampilan Berbahasa Secara Terpadu dengan Pendekatan Focus On Form. Jurnal Pendidikan dan Pembelajaran, 23 (2), 96-104.

Susanti, Ratna. 2016. “Analaisis Kesalahan Berbahasa pada Penulisan Iklan Luar Ruang di Kota Surakarta. Jurnal Sainstech Politeknik Indonusa Surakarta”. Vol. 2, No. 5, ISSN 2355-5009.

Syahriandi. 2014. "Analisis Kesalahan Berbahasa pada Media Serami Indonesia". Garuda. Vol. 2, No. 1, ISSN 2338-0306.

(http://download.portalgaruda.org/article.php?article $=183288 \& v a l=6$ $354 \&$ title $=$ Analisis $\% 20 \mathrm{Kesalahan} \% 20 \mathrm{Bahasa} \% 20$ pada $\% 20 \mathrm{Media} \%$ 20Serambi\%20Indonesia). Diakses pada tanggal 10 Maret 2018.

Tarigan, D.,Sulistyaningsih. 1996. Analisis Kesalahan Berbahasa. Jakarta : Depdikbud.

Wijayanti, Rohmah Dwi. 2014. "Analisis Kesalahan Berbahasa Bidang Morfologi pada Karangan Narasi Siswa Kelas VII Madrasah Tsanawiyah Muhammadiyah 1 Weleri Tahun Ajaran 2013/2014". Varia Pendidikan. Vol 5, No. 3, ISSN 1342-1254. (http://ejournal.varia pendidikan.ac.id/index.php/jret). Diakses pada tanggal 16 Maret 2018 